\title{
ПРОБЛЕМИ ФОРМУВАННЯ ВИХОВНОГО ІДЕАЛУ В ТВОРЧОСТІ ЛЕСІ УКРАЇНКИ
}

\section{Т.О. Білан}

Серед вагомих, але недостатньо опрацьованих філософських проблем, е проблема виховного ідеалу. Ідеал як загальна форма цілепокладаючої діяльності пронизує все суспільне буття людства, і зрозуміло, що саме ця тема «стягує» воєдино духовне та матеріальне життя людства. Виховний ідеал відображає наявне суспільне буття і в ньому закладене майбуття його. Стержнем ціеї завжди актуальної проблеми є світоглядна орієнтація суспільства, його ментальність, а в зв'язку 3 тим, що сфера світогляду належить до центральних проблем філософії, категорія виховного ідеалу, його змістовне наповнення $є$ суто філософською проблемою, зміст якої не достатньо відтворений в наявних розробках. Виховний ідеал в філософському розумінні - це детермінована часом і простором така модель особистості, яка гармоніюе з суспільним цілим і знаходить вираження у вільному і універсальному розвитку людського буття. Духовне життя українського народу протягом сторіч було обмежене і контрольоване тими державними системами, до складу яких входила Україна, і не набуло самостійного вираження в науковій і філософській літературі. Критеріями необхідності висвітлення даної проблеми є реалії сьогодення: формування національної еліти, розуміння української літератури як недиференційованої світоглядно-філософської системи, адже українську історіографію, педагогіку, етнографію, філософію репрезентуе ряд діячів української літератури. Це і сприяло посиленню інтересу до питань розробки виховного ідеалу в спадщині літературних діячів України. Особливе місце серед них належить Лесі Українці, творчість якої вийшла далеко за межі свого часу, так і навіть свого народу, і вира-

Актуальні проблеми духовності:

зб. наук. праць / Рет.: Я.В. Шрамко

Вип. 11. - Кривий Piг, 2010, 160-167 
зила ідеї, які лише зараз здійснюються в духовнім процесі світового та національного рівня. Творчість Лесі Українки розглядалася у межах літературознавчої науки і фактично у ХХ столітті залишалася за межами вітчизняних філософських досліджень, а її ідеал досконалої особистості майже не відомий.

Серед численних питань, які складають панораму педагогічного процесу в цілому, одним із найважливіших $е$ питання його змістового наповнення. Адже, крім знання «технологічних особливостей» формування тих чи інших рис людської особистості (на що і спрямований весь освітньо-виховний процес у цілому), найголовнішим, на наш погляд, є проблема визначення тих світоглядних орієнтирів, які становлять сутність так званого «виховного ідеалу». Як відомо, навіть у найпростіших формах праці завжди присутній не тільки «проект» тих дій, які допоможуть зробити цю працю, а й те, що становить саму сутність дії- - чітке уявлення про результат, який плануеться отримати. Тим більше це стосується й такого складного «предмета», як майбутній член суспільної спільноти. Але ж, як це визначили сьогоднішні педагогіка, соціологія, філософія, уся ця проблема спирається саме на світоглядно-філософські принципи педагогічного процесу в цілому. Тому проблема «виховного ідеалу», яка, в основному, зафіксована в конкретно-педагогічних знаннях, виходить за їі межі й набувае певного світоглядно-синтетичного, тобто філософського змістового наповнення.

Сьогодні, коли ми прагнемо осмислити минуле, коли відбулося ста-

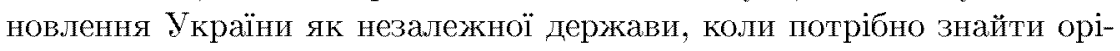
єнтири на майбутне, - необхідний якийсь узагальнюючий та проникливий погляд на душу народу, що виявляється в національному характері. Національний виховний ідеал повинен випливати із загальнолюдського, він, підтверджуючи вселюдські цінності, доповнюеться тими рисами, які притаманні ментальності даного народу, адже людина «входить у людство через національну індивідуальність - як людина індивідуальна, а не абстрактна, як росіянин, німець, англієць. Людина не може перескочити через цілий ступінь буття, від цього вона зубожіла б і спустошилася. Національна людина - щось більше, а не менше, ніж просто людина, у ній є i родові риси людини взагалі, i риси індивідуально-напіональні» $[1$, с.4]. У свою чергу, виховний ідеал народу залежить від його державного устрою, світогляду, релігії, моралі, від рівня розвитку культури. Дослідження української ментальності як специфічного світобачення нашого народу неможливе без аналізу тих складових, які входять у дане інтегративне поняття. Однією з ва- 
жливих рис, що характеризуе ментальність народу, є його уявлення про цінність людини як особистості. За умов національного відродження української культури, зміни соціальних орієнтирів, більш високі вимоги висуваються перед окремою людиною, її потребами, бажаннями. Стає зрозумілою роль кожного індивіда, особистості як активного творця нового.

Традиція поєднувати культуру 3 розвитком людини, зі «створенням» її душі й тіла, з моральною та розумовою освітою індивіда, походить ще 3 античності й постійно відтворюеться в нові часи. Ця традиція розглядае людину не як «продукт» природи, а як «продукт» виховання, спрямованого на «культивування» в ній окремих навичок, умінь, здібностей і поглядів, які уможливлюють життя в суспі.льстві. I якщо в процесі «перероб́ки» природи створюється культура речей, то через виховання формується культура людей, самі люди як культурне суспільство. Кожен конкретний народ через свою національну систему виховання органічно продовжує себе в своїх дітях, генезуе національний дух, менталітет, характер, психологію, традиційну родиннопобутову культуру, спосіб життя.

Український народ, маючи свої етнонаціональні особливості, своє призначення, на засадах християнства й загально-европейської культури творить свій національний український виховний ідеал. При цьому не можна не враховувати зміну його відповідно до зміни історичних умов життя нації, але не можна й забувати, що кожна нація $є$ «індивідуальністю» зі своїми біологічними, психічними та світоглядними властивостями характеру, які себе відлзеркалюють у культурі народу. У відомого українського культурного діяча І. Лисяк-Рудницького читаємо, що «національний характер тотожний із своєрідним способом життя, комплексом культурних вартостей, правилами поведінки та системою інституцій, які притаманні даному народові. . , кожен народ має власні шляхи розвитку, і свій власний досвід життя, який завершується його ідеалами життя» $[6$, с. 9-10].

Звичайно, усі ці проблеми мають для нас не тільки абстрактний, а й певний конкретний характер. Це виражається насамперед в тому, що в умовах творення національної державності та відродження національної культури сам виховний ідеал так чи інакше пов'язаний 3 проблемою національної ідентичності. Саме тому потрібне осмислення ідейних основ українського національного виховання та виховного ідеалу, що випливае 3 них, одночасно виникае потреба зазирнути в творчу спадщину діячів української культури, яка містить безперечний виховний потенціал, котрий нам потрібно виявити, проаналізу- 
вати, ідентифікувати 3 епохою створення й сьогоднішнім днем, при цьому, витлумачуючи цей потенціал з урахуванням особистості і перипетій долі автора, контексту епохи, усього створеного ним до і після аналізованого твору. Але для цього необхідне не тільки загальне розуміння питань, а й розуміння світоглядно-філософських поглядів тих мислителів, які особливо активно вплинули на вироблення ідеалів національної культури.

Особливо цікавою щодо цього е творчість Лесі Українки, що, відображаючи свою епоху, спромоглася зазирнути в майбутне і тим самим стала воістину нашою сучасницею. На наш погляд, найбільш показовим буде звернення до проблем виховного ідеалу, поставлених у твоpax Лесі Українки, тим більше, що творчість письменниці спрямована думкою у XXI століття. Зрозуміти сутність складних світоглядних орієнтирів письменниці можна, лише звернувшись до розгляду шляхів формування виховного ідеалу, якими пройшла сама поетеса. В $\dddot{1}$ творчості поставлено проблеми, що хвилюють людство з часу «пробудження» людської думки й донині: проблеми краси, істини, людського буття, мистецтва, особистості й суспільства, адже вона дошукувалася «тої мистецької рівноваги, що робить твір класичним, тої певності, яка нічого не боїться», щоб «пересадити почування свого народу на грунт одвічних вселюдських змагань» $[4$, с. 130$]$.

Піклування Лесі Українки про розвиток національної культури, прагнення винести її на рівень передових культур Європи, турбота про освіту, статус рідної мови серед інших мов, мораль диктуеться тими складними соціально-політичними умовами, які склалися в Україні на межі XIX-XX століть, але національне життя за таких обставин не зникло, а лише набуло нових форм, і потужним чинником українського національного руху стає література, адже «ведучи мову про українську філософську традицію у XIX, а потім у XX столітті, варто мати на увазі, що вона, здебільшого, виражається у непрофесійній сфері. Часто вартісні для українців філософські ідеї знаходили вияв у художньо-літературних творах, іноді в творах публіцистичних, які були більш придатні для філософування» [5, с. 17]. Дмитро Чижевський зазначає, що саме на рубежі століть нова українська культура вперше набуває «повної структури»: не тільки художньо-естетична, а й наукова, релігійна, політична «підсистеми» українського духовного життя складаються й розвиваються органічно, «з середини», відповідно до потреб української суспільності.

Микола Зеров у розвідці про Лесю Українку наголошуе на тому, що «справжнім пафосом» іï творчості було розв'язування загально- 
людських проблем та вічних колізій, найулюбленішою ї̈ сферою був світ ідей, а її творчість, на думку М. Зерова, стала «голосом грунту», страждати примушувала не відсутність образів, а переобтяженість ними. Мандрівні образи були її постійними супутниками, повз її думку не проходило ні одне ідейне зворушення сучасності. Лабораторією формування цих загальних ідей були, на наш погляд, її заняття історією. Так, ще з дитячих років Олена Пчілка робила все для того, щоб Леся допомагала їй у навчанні та вихованні молодших сестер і брата. Наприклад, для сестри Ольги, Леся навіть сама складала підручники 3 різних дисциплін, а наймолодша сестра Ізидора згадує, що ї̈ вчила майже виключно Леся. Одним із таких підручників була «Стародавня історія східних народів», що свідчить про розуміння нею ролі систематичного і послідовного викладення курсу історичних знань у формуванні світогляду молодої людини. Леся Українка в своєму підручнику подає бачення національного виховання, в різних частинах підручника вміщені зауваження, міркування, що дають змогу створити ясну, цілеспрямовану систему виховання, виявити засади народного світогляду, знайти способи самопізнання. Трактування історичного процесу в підручнику виховувало національну свідомість, ідентифікувало історичні факти до сучасних подій, будило національну самосвідомість. Відмінність у рівнях культурного розвитку народів Леся Українка пояснюе не тільки особливими «фізичними і психічними» якостями, а й тим, що «одні люди запанували над іншими, другі знов самі попали у неволю». Привертає увагу високий моральний ідеал, що випливає 3 контексту підручника. Леся Українка не оминае принагідної можливості для виховання чесності, правдивості, що завжди осмислені в культурі будь-якого народу. Створений Лесею Українкою підручник був спрямований на виховання в молоді національних, поглядів і суджень, цей підручник репрезентував читачеві по-справжньому наукове розуміння історичних явищ, розуміння культуротворчих чинників життєздатності народу.

Нову художню концепцію буття оригінально втілено Лесею Українкою в морально-етичній сфері, зокрема авторські ідейні акценти зосереджуються, як правило, у площині людини, її самосвідомості. Епоха, на яку припадае творчість Лесі Українки, відзначається підвищеною увагою до моральних проблем, глобальний перегляд головних філософських категорій у естетиці того часу потребував нового співвідношення конкретного й загального, особ̆истого й суспільного. Епоха кінця XIX - поч. XX століття характеризується активізацією філософських шукань в українській культурі, літературі зокрема. Схильність 
Лесі Українки до філософського осмислення дійсності відзначалась багатьма дослідниками.

Об'єктом загального інтересу в культурі кінця XIX та початку XX століття стають філософські аспекти самоусвідомлення людини. Багатий духовний світ сучасника, сильні пристрасті й тонкі переживання привертають увагу поетів-ліриків. Імперативи часу повною мірою стосувалися і творення нового типу людини, гармонійної особистості. Поетичний світ Лесі Українки, як вказував дослідник її творчості Адам Войтюк, складається із трьох сфер: а) «літосфери»-камінного світу ще ненародженого або вже померлого життя, наскрізними символами якого виступають образи каміння, скель, первісного хаосу; б) «біосфери»-світу природно-біологічних інстинктів і пристрастей, який позначається образом «червоної троянди», або «квітки граната»; в) «ноосфери» - світу високого людського духу і розуму, символами цього світу $е$ образи «блакитної троянди» та «чаші святого Грааля». «Співвідношення між вище відзначеними сферами мас ієрархічний характер. Перехід персонажа з нижчої сфери до вищої характеризуе його в позитивному плані», - підкреслюе вчений [3, с. 20-21]. Названі вище сфери можуть бути своєрідним «ключем» до тлумачення екзистенційних проблем творчості Лесі Українки, а «символічне мислення» (за М. Євшаном) Лесі Українки детермінуе ідеал особистості. Витоки яскравої авторської своєрідності лірики поетеси слід шукати в концептуальному переосмисленні зв'язку «суб'єкт-об'єкт», а визначальною рисою ліричного стилю Лесі Українки $є$ те, що кожна її особиста тема, зростаючи до найбільших епохальних узагальнень, набуває смислу і значення лише в міру своєї громадської значущості. Нерозривна єдність особистого і загального, «свого» $\mathrm{i}$ «чужого» органічно властива творчості поетеси.

Основні художньо-філософські площини творчості Лесі Українки це площини реальності й ідеалу, дійсності і мрії, думки й почуття, явища і сутності. У межах цих площин з'являеться новаторське трактування етичних цінностей та їх взаємного співвіднесення. Творчість Лесі Українки визначає екзистенційну домінанту особистості. У вірному, несхитному, навіть самовідданому служінні духовному визволенню людини, у діянні на благо людини поетеса бачила призначення свого героя. Ця істина й формуе моральний імператив, якому підлягае свідомість Лесиної особистості у найскладніших ситуаціях вибору. Такий моральний імператив $є$ отим «голосом душі», шо не дае людині «схибити» навіть у найважчі моменти. «Можна все згнітити, - писала поетеса, - за винятком голосу душі,- він дасть себе почути і в дикій 
пустелі, і серед натовпу, і навіть перед царями» [7, с. 291]. Твердість, незламність духу лежить в основі Лесиного екзистенціалізму, поетеса переконана: випробування не зломлять, а загартують сильну духом особистість. Особистість у творчому доробку Лесі Українки постійно відкрита для самовдосконалення, самоаналізу, творчості, гостро відчувае потребу ставити і розв'язувати актуальні питання доби. Поетеса приходить до нового розуміння ідеалу як підсумку й домінанти життєвого діяння, активної позиції. Досягнення ідеалу, душевної гармонії можливе тільки за умови проходження різних випробувань, суспільних страждань. Концепція особистості, котру знаходимо у спадшині Лесі Українки, підносить кращі людські якості - цілісність характеру, громадську самовідданість, силу волі, прометеївський духовний порив, відвагу, гордість. Важливе місце в художньо-філософській концепції нової людини Лесі Українки займає проблема духовної свободи особистості. Власне, це чи не найголовніша філософська проблема, яка споконвіку хвилюе людство - усвідомлення відносної обгрунтованості своїх переконань, і непохитне обстоювання їх - це і різнить цивілізовану людину від «варвара». Також важливим $е$ «для людини і суспільства... надання повної свободи людській натурі для тї поширення в незліченних і суперечливих напрямках» [2, с. 232]. Леся Українка своєю творчістю досліджуе світ як цілісність у його розвитку й суперечностях, виявляє чималий інтерес до проблеми людини, умовно накреслюючи модель духовно незалежної, активної особистості індивідуалістичного самозаглиблення. Цим вона формує характерологічні риси екзистенційного світобачення з усім багатством внутрішнього «руху особистості».

Таким чином, можемо дійти висновку, що в контексті філософськолітературної традиції шодо особистісного виміру українського виховного ідеалу важливе місце займають питання, пов'язані з іделлом «нової людини», достатньо глибоко зануреної в глибини національного світобачення i, разом з тим, широко відкритої до досягнень європейської духовної культури. Дослідження проблеми формування виховного ідеалу в творчості Лесі Українки та його обумовленості традиціями української духовності потребує глибокого проникнення в «реальні» (Бубер) проблеми української культури, що є характерним для українського національного відродження XIX - поч. XX століть. Саме на рубежі XIX - поч. XX століть нова українська культура вперше набувае «повної структури»: не тільки художньо-естетична, а й наукова, релігійна, політична «підсистеми» українського духовного життя складаються й розвиваються органічно, «зсередини», відповідно 
до потреб української спільності (Д. Чижевський). 3 цього приводу доцільним є дослідження філософії української ідеї, що є своєрідним детермінантом становлення виховної парадигми в даний період. I саме Лесі Українці належить чимала роль у розвитку й формуванні національної свідомості українського народу, української ідеї, адже незаперечною є в її спадщині присутність напруги філософсько-поетичної мислі, готовність до героїчного чину в ім'я особистої і національної свободи, пропонуючи виділити «феномени» 3 «ноуменної» діяльності, поетеса розробляе в світовій літературі нове філософсько-гуманістичне світобачення проблеми особистості, яка орієнтована на неповторну цінність кожного людського буття.

\section{1 Бібліографія}

[1] Бердяев Н. Національність і людетво // Сучасність. - 1993.№ 1. - C.154-157.

[2] Берлін I. Чотири есе про свободу. - К.: Основи, 1994.

[3] Войтюк A. Блакитна троянда. Корифеї рідного слова. - Дрогобич: Відродження, 1991. - С. 31-40.

[4] Гатальська С.М. Філософія культури. - К.: Либідь, 2005.

[5] Кралюк П.М. «Білі плями» в історії української філософії.Луцьк: ПВД «Твердиня», 2007.

[6] Лисяк-Рудницький I. Історичні есе. У 2 т.-К.: Основи, 1994. T. 2 .

[7] Украйнка Л. Твори: В 4 т. - Т. 4.: Оповідання; Статті; Листи /Упоряд. Н. Вишневська. - К.: Дніпро, 1982.

Надійла до редакиї 28 лютого 2010 р. 